\title{
Symbolické hranice mezi sociálními světy
}

\author{
Symbolic Boundaries between the Social Worlds \\ Jitka Sklenářová
}

\begin{abstract}
The gap between the rich and the poor is getting wider, and the income differences in some areas of the Western world have reached their highest levels since the Great Depression in the 1930s. More and more governments are therefore facing the problem of growing indignation among their citizens - thousands of dissatisfied people are joining movements and protesting against "the system" around the world. Considering such events, it might be tempting to interpret differences in social strata entirely in terms of socioeconomic characteristics. In this text, I use some specific examples of social institutions to introduce how a cultural-sociological concept of symbolic boundaries helps us to develop a more complex understanding of the social differences issue. This concept is very helpful because it adds some additional dimensions to the study of social exclusion. In the problem of relationships between individuals, such dimensions might play an even more important role here than socioeconomic status.
\end{abstract}

KEY WORDS symbolic boundaries, social worlds, inequality, incommensurability, unemployment, individualization, classes

Demokratické postindustriální společnosti se potýkají s nárůstem nerovnosti mezi bohatými a chudými, tzv. rozevíráním nůžek, jehož konsekvencemi se zabývá Jan Keller v knize Tři sociální světy (2010). Zároveň zde kritizuje současné sociologické myšlení a jeho představitele za to, že před onou situací zavírají oči či odvrací pohledy jinam: Namísto analýzy mechanismů reprodukce majetku a moci je údajně ,,pozornost odváděna ke studiu horizontálních sítí, v nichž prý každý podle své vlastní volby reprodukuje svůj sociální, kulturní a symbolický kapitál“ (Keller 2010: 9). Mezitím jsme však svědky konce společnosti charakteristické spojitě odstupňovanou nerovností a nástupu „naprosté majetkové, mocenské a sociální nesouměřitelnosti“" (tamtéž).

Současné společnosti se podle Kellera rozpadají do tří sociálních světů, jež jsou charakteristické nesouměřitelností svých životních podmínek. Pokud však existují sociální světy založené na absolutní nerovnosti, musí mezi nimi existovat hranice. Hranice ve společnosti chrání nerovnosti a rozlišují jednotlivce na ty, kteří je mohou překročit, a na ty, kteří je překročit nesmějí (Lamont a Fournier 1992: xiii). A jsou to právě symbolické hranice, jež

Sociálni studia. Katedra sociologie FSS MU, 4/2012. S. 27-44. ISSN 1214-813X. 
bychom měli podle Michèle Lamont (1992: 6) ,považovat za nutnou, nikoli však dostačující podmínku vytváření nerovnosti a exkluze, za často nezamýšlený důsledek procesu vymezování vlastní identity“. Studiem hranic, které vytvářejí různé skupiny jedinců, lze poznat povahu a dynamiku vztahů a nerovností mezi těmito skupinami. Koncept symbolických hranic nemá předem určený obsah, a tak do něj lze zahrnout nejrůznější faktory, jež tvoří znaky vysokého statusu, a to v různých oblastech i obdobích (tamtéž: 128).

Keller se od podobných teorií distancuje a i ve své nové práci tvrdí, že vymezování vlastní identity na základě symbolických hranic ve skutečnosti jen zastírá služebné postavení středních vrstev (Keller: 2012: 127). Sám se raději odvolává na sociologický odkaz Marxe a Webera a ostře se staví proti odmítnutí třídní analýzy společnosti s tím, že právě svou třídní př́íslušnost si lidé zkrátka neuvědomují. „Muselo by se navíc ještě prokázat, že ony objektivní procesy v oblasti výroby, o nichž klasická třídní teorie hovoří, životy členů společnosti nijak výrazně neovlivňují. A pak by samozřejmě bylo nutno také objasnit, co tedy reálně jejich životy ovlivňuje“ (Keller 2010: 123).

V tomto př́spěvku bych ráda prezentovala odlišné stanovisko, které lze shrnout slovy Jeffreyho Alexandera (2007: 3): „Kultura je vzhledem k sociálním strukturám, které ji obklopují, relativně autonomni“ $Z$ toho plyne, že při analýze vytváření a reprodukce nerovností bychom měli zkoumat nejen jejich materiální podmínky, ale soustředit se rovněž na konstrukci významu. „Pokud je význam ve vztahu k politickým a ekonomickým silám relativně autonomní, pak mohou kulturní struktury konkurovat jejich dominantní síle“ (tamtéž: 4). Mým cílem je rozššřit Kellerovo pojetí trrí sociálních světů o kulturně-sociologický koncept symbolických hranic. Autor sám existenci těchto hranic nereflektuje, ačkoli ji v textu lze implicitně objevit ${ }^{1}$ - různé společenské instituce mají podle něj pro jednotlivé sociální světy různý význam, což přítomnost symbolických hranic indikuje. Keller ovšem mezi druhy těchto hranic nerozlišuje a v jeho díle se objevuje neskrývaný ekonomický determinismus:

$[\mathrm{N}]$ ežijeme v žádné postmoderní době. Prvky postmoderní mentality, které se ve vzdělanějších a kvalifikovanějších vrstvách staly módou, spolehlivě brání vidět spjatost sociální struktury s ekonomickými vztahy na straně jedné a podmíněnost individuálních hodnot a postojů sociální strukturou na straně druhé. (Keller 2010: 129)

Kromě obohacení Kellerova textu se též snažím upozornit na jisté limity, které se v jeho práci objevují např́ílad v souvislosti s pojetím nezaměstnanosti, individualizace či existence tříd v postindustriálních společnostech.

Na úvod se pokusím nastínit pojetí konceptu symbolických hranic tak, jak s nimi autoři pracují v současnosti, ale i v souvislosti s jeho historickým vývojem pod vlivem Pierra Bourdieuho. V dalším oddíle stručně charakterizuji Kellerovo pojetí společnosti nesouměřitelnosti včetně rozdělení na jednotlivé sociální světy. Analytická část textu se následně

Potvrzuje tím postřeh Lamont (2001), která upozorňuje, že někteří autoři analyzují práci s hranicemi (boundary work), aniž by při tom využivali jazyka symbolických hranic. Pro výraz boundary work nelze $\mathrm{v}$ dostupné sociologické literatuře ani v rámci českého jazyka najít vhodnější významový ekvivalent, než je právě ,práce s hranicemi“. Boundary work totiž zahrnuje veškerou práci s hranicemi - jejich vytváření, změny i mizení. 
zaměřuje na symbolické hranice, které lze mezi Kellerovými světy najít, na jejich podobu a srovnání se zjištěními z výzkumů Lamont (1992, 1998, 2000).

Největší omezení této práce vyplývají především z nedostatku literatury a výzkumů věnovaných tematice elit; vycházím z Kellerova popisu, jenž se takřka výhradně opírá o dílo manželů Pinçonových (Keller 2010). Jde o prakticky jediné výzkumníky, kterým se podařilo do horního patra společnosti proniknout, nepočítáme-li příspěvek Charlese Wrighta Millse (1966). Informace o životě středních a nižších vrstev přebírám z výzkumů Lamont. Hledání symbolických hranic mezi sociálními světy je tak limitováno na př́klady Spojených států a Francie. Ve výsledku jde ale spíše o výhodu, nebot' údaje, na nichž staví Keller, pocházejí především z těchto států.

\section{Symbolické hranice v sociologii}

Ve snaze porozumět roli, kterou hrají symbolické zdroje při vytváření, zachovávání či mizení institucionalizovaných sociálních rozdílů, jako jsou třída, rasa nebo gender, je podle Lamont a Molnára (2002) důležité rozlišovat mezi hranicemi symbolickými a sociálními. „Symbolické hranice jsou konceptuální rozdíly vytvářené sociálními aktéry pro kategorizaci předmětů, lidí, praktik, dokonce i prostoru a času“ (tamtéž: 168; zvýraznění JS). Vyjadřují je jak normativní zákazy (tabu), tak také kulturní př́istupy a praktiky či principy vzniku sympatií a odporu (Lamont 2001: 15 341). Jejich studiem lze zachytit dynamiku sociálních vztahů mezi soupeřícími skupinami. Symbolické hranice totiž rozdělují jedince do skupin takovým způsobem, že ,zahrnují a definují určité osoby, skupiny a předměty, zatímco vylučují ty ostatní“ (Epstein 1992: 232). Jsou rovněž prostředkem pro získání statusu či monopolizaci zdrojů (Lamont a Molnár 2002: 168).

Setkají-li se symbolické hranice se všeobecným uznáním, mohou významným způsobem omezovat a strukturovat sociální interakci. Jen tehdy se mohou stát hranicemi sociálními a získat tak charakter sociální exkluze či třídní a rasové segregace (Lamont a Molnár 2002: 168), či vést $\mathrm{k}$ diskriminaci, přehnanému výběru či sebe-eliminaci jedinců nižšího statusu (Lamont 1992: 178). Sociální hranice lze tedy definovat jako objektivizované formy sociálních rozdílů, které se projevují v nerovném prrístupu, distribuci zdrojů a sociálních příležitostí (tamtéž). Tilly (2005: 134) o sociálních hranicích hovoří jako o zónách mezi oblastmi rozdílné hustoty vnitřně propojených klastrů populace. Tyto hranice přitom nezahrnují pouze demarkační linie, ale rovněž vztahy na jednotlivých stranách hranic, napříč jimi a sdílená vyprávění o těchto vztazích (tamtéž: 173). „Symbolické a sociální hranice by však měly být považovány za stejně reálné. Jedny existují na intersubjektivní úrovni, zatímco existence těch druhých se projevuje sdružováním individuí" (Lamont 1992: 169). Lamont také hovoří o vztahu symbolických hranic k hranicím sociálním jako o „nutné, nikoli však dostačující podmínce vzniku socioekonomické nerovnosti“ (tamtéž: 178).

Výzkum symbolických hranic mezi třídami se zabývá kulturní spotřebou, indikátory trrídy, reprodukcí nerovnosti a způsoby, jak trrídní nerovnost ovlivňuje utváření osobnosti (Lamont a Molnár 2002: 172). Zájem o studium symbolických hranic a jejich vlivu na reprodukci sociálních nerovností se $\mathrm{v}$ sociologii objevil zanedlouho po rozššřrení díla Pierra Bourdieuho. Ten v knize La Distinction (1996 [1979]) představuje první obecný model 
vztahu kultury k sociálním a materiálním faktorům, v němž chápe třídu jako determinující a zároveň determinovanou sílu (Wilson 1988: 60).

Bourdieu (1996) se při výkladu nerovností opírá o koncept habitu, s jehož pomocí vysvětluje souvislost mezi sociální pozicí jedinců a jejich praktikami. Habitus je internalizovanou potřebou měnící se $\mathrm{v}$ dispozici, která následně produkuje určité praktiky ${ }^{3}$ a způsoby vnímání světa. Jiné podmínky existence tedy produkují jiný třídní habitus, který pak vytváří praktiky charakteristické pro skupiny aktérů ve stejných životních podmínkách, tj. v rámci objektivní třídy (tamtéž: 101, 170). Na rozdíl od Veblena a jeho představy okázalé spotřeby (1999) se však Bourdieu domnívá, že vysílané distinktivní signály jsou často neuvědomované, protože jde o projevy vtělených dispozic (habitu) a chování naučeného v průběhu socializace (Lamont a Lareau 1988: 158). Bourdieu také ukazuje, že vkus se mění spolu s vlastnictvím ekonomického a kulturního kapitálu. Kulturní kapitál přitom považuje za indikátor i základ tř́́dní pozice, jenž demonstruje distanci od kulturních praktik a preferencí, které jsou běžné a masové, a tedy charakteristické pro obyčejné lidi (Bourdieu 1996: 31-32). Vládnoucí třída zároveň dominovaným vnucuje určité významy jako legitimní, a to pomocí zastírání mocenských vztahů, na kterých se zakládá její síla (Bourdieu a Passeron 1990: 4). Moc vycházející z vlastnictví kulturního kapitálu tak dominujícím umožňuje ovlivňovat životy jiných za využití exkluze a symbolického násilí (Lamont a Lareau 1988: 159), zatímco umění a kulturní spotřeba legitimizují sociální rozdíly4 (Bourdieu 1996: 7).

Michèle Lamont (1992: 128) na základě výsledků studie, která zjišt’uje, zda a za jakých podmínek by mohly hranice načrtnuté dotazovanými vést $\mathrm{k}$ třídní reprodukci, rozděluje symbolické hranice na tři typy. Význam, který jednotlivým hranicím dotazovaní prripisují, se v jednotlivých kulturách - americké a francouzské - liší. Jednotlivci totiž „nevytváří hranice na základě své vlastní zkušenosti: vypůjčují si je z hlavních kulturních repertoárů, jež jim poskytuje společnost“ (tamtéž: 6). Morální hranice se zakládají na morálním charakteru a soustředí se kolem hodnot, jako jsou čest, pracovní etika, osobní integrita či ohleduplnost vůči druhým. Lidé stavějící morální hranice nemají v oblibě podvodníky, kariéristy

2 Bourdieu definuje tř́́dy nejen na základě vlastnictví ekonomického kapitálu, ale pomocí objemu a proporce ekonomického a kulturního kapitálu, kterým socio-profesní skupiny disponují (Bourdieu 1996: 316).

3 Kritikové považují za jedno ze slabých míst Bourdieuho modelu skutečnost, že „,není jasné, jak by dispozice mohly produkovat praktiky“(Jenkins 2002: 79).

4 Bourdieuho teorie je podrobována neustálé kritice. Halleova studie ukazuje, že kulturní spotřeba nemusí nutně vytvářet hranice, nebot' například žánr krajinomalby se těší oblibě např́íc všemi sociálními skupinami, a že souvislost vysoké kultury s členstvím ve vyšších kruzích je neprokázaná (Lamont, Molnár 2002: 173). Další autoři pak odmítají Bourdieuho pojetí dominantní tř́́dy jako exkluzivní a netolerantní vůči kulturám jiných tř́́d. Bethany Bryson (1996: 895) zjistila, že respondenti s vyšším dosaženým vzděláním mají tolerantnější hudební vkus než jedinci s nižším vzděláním - nikoli však nevyhnutelně. Exkluze údajně souvisí s tř́́dním postavením tak, že žánry nejméně oblíbené u tolerantních jedinců patří k žánrům, jež nejvíce oceňují lidé s nejnižším vzděláním (tamtéž). Peterson a Kern (1996) zase ukazují na změnu vkusu vyšších tříd - výsledky jejich výzkumu říkají, že snobismus je ve Spojených státech nahrazován „kulturním všežroutstvím“ (cultural omnivorousness). 
a darebáky. Socioekonomické hranice berou v potaz sociální pozici jedince, již indikuje bohatství, moc či profesní úspěchy. Kulturní hranice pak mají svůj základ ve vzdělání, inteligenci, způsobech, vkusu a vyhledávání vysoké kultury (Lamont 1992).

$\mathrm{Na}$ základě svých kvalitativních dat Lamont soudí, že „Bourdieu silně podceňuje důležitost morálních hranic, zatímco zveličuje důležitost hranic kulturních a socioekonomických“ (Lamont 1992: 5). Keller (2010) rovněž kritizuje Bourdieua za zdůrazňování role kultury při reprodukci třídních rozdílů, sám ovšem staví výhradně na hranicích socioekonomických. Symbolické hranice, jimiž se zabývá Lamont (1992), pro něj představují víceméně jen jakési iluze středních vrstev „,o tom, jak bezchybní a vzorní jsou co do míry své ekonomické úspěšnosti, stupně své morální poctivosti i osobní kultivovanosti““ (Keller 2012: 127). Podívejme se tedy nyní, jak si současnou společnost představuje Keller.

\section{Tři sociální světy a teorie nesouměřitelnosti}

Teorie sociální stratifikace, jež jsou mezi některými autory stále populární, odpovídají podle Kellera (2010: 177) spíše poválečnému stavu společnosti než tomu dnešnímu; protože se zaměrují na poměřování kvantity, nedokážou vyjádřit kvalitativní odlišnost světa elity od světa deklasovaných. „Od poslední čtvrtiny 20. století se ovšem prudkým tempem množí známky toho, že relativní, spojitá a jemně odstupňovaná sociální nerovnost je opět nahrazována absolutní, diskontinuitní, nejednou až brutální nesouměřitelností“ (tamtéž: 10-11). Pro popis současných poměrů ve společnosti proto Keller navrhuje použít metaforu tří samostatných sociálních světů, do kterých se rozpadá dřive spojitá pyramida majetku, moci a prestiže a které fungují svou vlastní logikou a „,vzdalují se jeden druhému a všechny společně hodnotám otevřené společnosti“ (tamtéž). Rozdělení na sociální světy umožňuje vystihnout odlišné vlastnosti jednotlivých částí společnosti a kvalitativní rozdíly mezi nimi, jež se objevují v důsledku nárůstu nesouměřitelnosti (jak majetkové, tak mocenské i sociální), kdy kvantita odlišností roste do té míry, že se mění v jinou kvalitu: „Nemá pak př́liš smyslu měřit, o kolik je na tom kdo lépe, anebo hůře, protože odlišnosti se už odvíjejí v různém prostoru“ (tamtéž).

Základem veškeré logiky tří sociálních světů je rozdělení na ty, kdo jsou v rámci systému skutečnými držiteli moci a vlivu, dále na ty, kdo jsou z hlediska potřeb mocných a celého systému jakkoli využitelní, a konečně na ty, které ti nahoře, ani ti uprostřed prakticky k ničemu nepotřebují (Keller 2010: 196).

\section{Elita, deklasovaní a ti ostatní}

Nejvyšší patra společnosti obývají příslušníci elit. Jejich pozice jim umožňuje žít specifickým životem v izolaci od „obyčejného prostředí obyčejných mužů a žen“ (Mills 1966: 22). Keller (2010: kap. 3) rozlišuje elity na diskrétní a pomocné, což je dělení podobné Millsovu (1966), jež hovoří o ,jádru elity“ a jejích „okrajových vrstvách“. Zatímco první kategorie se pyšní rodovou tradicí a rozsáhlými majetky předávanými z generace na generaci (Pinçon a PinçonCharlot in Keller 2010), př́slušníci pomocné elity vděčí za své postavení profesní činnosti a jsou často obměňováni: „,musí se s nimi dovedně zacházet, získávat je lichocením, likvidovat je, anebo je povýšit do vyšších kruhů“ (Mills 1966: 347). „Obě patra elity mají odlišné 
vlastnosti a v mnohém odlišný životní styl, pohybují se zpravidla v různém prostředí a zůstávají navzájem spíše odděleny“, dodává Keller (2010: 63).

Na opačném pólu společnosti nacházíme skupiny lidí, kteří jsou pomocí různých společenských procesů vystrnad’ováni ze svého místa ve společnosti, vylučováni z trhu práce a nuceni žít pod prahem chudoby. Takoví lidé bývají považovaní za podtř́du, sociálně vyloučené či prekariát; Keller se však kloní k označení deklasovaní. Svět deklasovaných charakterizuje nejistá či žádná práce, s tím spojené problémy s půjčkami, bydlením i v rodině - jak upozorňuje Možný (2008: 222), pro stabilitu manželství je důležitější spíše stabilita manželova př́ijmu než jeho výše. Typickými obět'mi deklasování jsou marginalizovaní dělníci, pro jejichž status je rozhodující rasová př́slušnost, etnicita, gender, věk a rodinná podpora. Od státu požadují sociální pomoc, odvolávajíce se na morální principy a právo na spotřební standard (Pakulski a Waters 1996: 124-125).

Střední třída pak často zahrnuje všechny s výjimkou extrémně bohatých a extrémně chudých (Ehrenreich 1989: 5). Jedná se o pestrou mozaiku „těch, kdo do středních vrstev patří mírou své kvalifikovanosti, postavením v hierarchii řízení, velikostí př́ijmu, anebo životním stylem“ (Keller 2010: 125). Pro popis těchto vrstev se proto nejlépe hodí Weberova (1978) kategorie statusu ${ }^{5}$, na němž si všichni příslušníci středních vrstev velmi zakládají (Keller 2010). Pro střední vrstvy je podle Kellera charakteristické i to, že začínají být ohrožena všechna její patra (tamtéž: 131). „Poté, co se širším vrstvám společnosti - mezi nimi nemalé části dělníků a řadových zaměstnanců - podařilo proniknout do středních vrstev, začíná těmto vrstvám v podmínkách globální konkurence hrozit úpadek a jejich př́slušníkům deklasování“ (tamtéž: 117). Podívejme se však nyní na konkrétní rozdíly mezi významem a funkcí některých společenských institucí a mechanismů pro členy jednotlivých sociálních světů, o nichž se Keller zmiňuje, podrobněji.

\section{Morální hranice}

Ačkoli se může zdát, že morálka přesahuje trrídní rozdíly, americká data ukazují, že při exkluzi na základě morálky jsou ve hře charakterové vlastnosti, které jsou lidem prrisuzovány na základě jejich trrídní př́slušnosti (Lamont 1992). Například nižší třídy v Americe se vůči „těm nahoře“ vymezují poukazováním na charakterové „vady“ př́íslušníkủ střední třídy, jako jsou nedostatek osobní integrity, respektu k druhým a nízká kvalita jejich mezilidských vztahů. Francouzští dělníci navíc popisují střední vrstvy jako vykořist'ující a na rozdíl od Američanů nemají ambice vystoupat po společenském žebříčku stejně vysoko jako ony (Lamont 2000).

Příslušníci amerických středních vrstev, především vysokoškoláci, kladou velký důraz na toleranci a flexibilitu (na rozdíl od př́slušníků tříd nižších). Jedná se hlavně o postoje k deviantnímu sexuálnímu chování (homosexualitě), etnickým menšinám či tématům

5 Weber odvozuje třídní postavení od kontroly statků, dovedností a př́ijmů, které jejich užívání přináší (souvisí tedy s postavením jedince ve sfére produkce). Oproti tomu status je nárokem na sociální uznání, vyjádřeným ve formě privilegií. Je určován stylem života, vzděláním a prestiží (může být zděděná či zaměstnanecká). Status může na třídní pozici záviset, ale není jí zcela determinován; může však také sám ovlivnit třídní pozici (Weber 1978: 302-306). 
týkajícím se svobody projevu či občanských práv. Lidé bez vysokoškolského vzdělání podporují spíše hodnoty zdůrazňující tradiční normy, úctu k rodinným a náboženským autoritám, osobní integritu a př́močarost. Důstojnost pro dělníky znamená schopnost stát si za svým a mít kuráž. Takové hodnoty se ovšem dostávají do sporu s flexibilitou či nekonfliktností, která se v USA na pracovišti vysoce cení (a je zároveň znakem vyššího statusu) (tamtéž).

\section{Význam profesní činnosti}

Podle Alexandera (1992: 292) lidé sami sebe vždy „definují pomocí pozitivních pojmů ze symbolického souboru“. Charakterové rysy, které příslušníci středních trríd oceňují na ostatních, jsou tak charakteristické právě pro střední třídy. Jak to vidí i Keller, ve středních vrstvách nejde jen o peníze a spotřebu na úrovni. „Neméně důležitý je pro ně pocit naplnění a hrdost nad tím, co dokázali. Také určitá autonomie a status spojený s výkonem náročné profese“ (2010: 61). Profese je tedy těmito lidmi vnímána jako významný prostředek osobnostního rozvoje, sebevyjádření a sebehodnocení (Lamont 2000). Mezi oceňované vlastnosti proto patří sebekontrola, rovnostářství, racionalismus a schopnost dlouhodobého plánování, v neposlední řadě také důvěryhodnost a dobrá pracovní morálka (tamtéž).

Dlouhodobé plánování je ovšem deklasovaným s neplnohodnotnými pracovními smlouvami znemožněno, upozorňuje Keller: „O budoucnosti raději neuvažují, nemají co plánovat. Orientují se pouze na bezprostřední současnost“ (2010: 99). Na tyto příslušníky nižší třídy, jejichž zaměstnání se stává čím dál méně motivující, co se týče odměny, statusu a možnosti seberealizace (Keller 2010: 96), pak shlíží příslušníci středních tříd jako na nedůvěryhodné osoby postrádající pracovní morálku. Tento poznatek adekvátně odpovídá na otázku, proč úspěch v zaměstnání často nekoreluje se schopnostmi daného jedince (Lamont 1992: 175-177). ${ }^{6}$

Reprodukci třídní nerovnosti tak lze považovat za nezamýšlený důsledek použivání třídně specifických kritérií hodnocení. Zatímco stř̌ední vrstvy jsou přesvědčeny, že „,profesní činnost je měřítkem morální hodnoty člověka“ (Keller 2010: 60), dělníci nepřisuzují své práci takový význam. Jistotu zaměstnání mohou vnímat jako kompenzaci nemožnosti kariérního růstu; dobrá práce pro ně znamená vysoký plat, bohaté odměny a stálý úvazek spíše než možnost mobility, kariéry nebo uspokojivého skloubení práce s vlastní osobností a zájmy (Lamont 1992: 176). Dělníci také považují svůj život za kvalitnější, než je život středních vrstev - tráví více času s rodinou a jsou méně omezeni pracovními povinnostmi (Lamont 2000: 230).

Zatímco Keller (2010: 23) tvrdí, že ,,[z]aměstnání se stává stále nejistější, činí zaměstnance stále méně odolným vůči výkyvům trhu, stále méně mu umožňuje čelit sociální nejistotě, či dokonce předjímat a budovat svou vlastní kariéru,“ ze závěrů Lamont (1992) jasně vyplývá, že dělníci o žádné budování kariéry nestojí. To vrstvám nad nimi logicky umožňuje obviňovat je $\mathrm{z}$ nedostatečné motivace $\mathrm{v}$ rámci jejich pracovního nasazení. Pokud pak o tom,

$6 \quad$ K podobnému závěru došli Bourdieu a Passeron (1990) ve své analýze reprodukce nerovností ve školství, kterou jsme již zmiňovali výše. Učitelé u svých žáků oceňují vlastnosti typické pro střední třídy, do níž kantoři sami náleží. Znevýhodňují tak děti z rodin s nižším statusem, od kterých rodiče vyžadují vlastnosti odlišné. 
koho zaměstnat a koho ne, rozhodují střední vrstvy, mohou při svém rozhodování uplatňovat právě kritéria hodnocení zvýhodňující vlastnosti typické pro příslušníky středních vrstev. Nezaměstnanost deklasovaných pak může být s poukazem na morální kvality středními třídami zpětně snadno interpretována jako nedostatečná snaha a píle, čili nedostatek pracovní morálky.

\section{Nezaměstnanost}

Pokud americký dělník o práci přijde, vina bude s největší pravděpodobností přenesena na něj. Jak Keller (2010: 45) upozorn̆uje, právě to je cílem amerického režimu workfare. ${ }^{7}$ Autor zde také tvrdí, že hlavním významem tohoto režimu je ideologie, kterou šírí. Ti, kdo doplácejí na ekonomické poměry, jsou díky ní obviňováni z lenosti a neschopnosti a př́íslušníci stř̌edních vrstev „kritizují státní intervence na pomoc nezaměstnaným, chudým a sociálně vyloučeným“ (2010: 59). „Dočasné, či trvalé vyloučení celých skupin z trhu práce, které je objektivně důsledkem přechodu organizací do sít'ové podoby a dalších procesů, je vydáváno za osobní selhání těch, kdo se stali obětí vývojových zvratů dynamiky trhu“ (tamtéž: 52). Přítomnost symbolických hranic mezi střední a nižší trrídou a jejich rozdílným vztahem k zaměstnání má však, jak ukázala Lamont, stejné důsledky, aniž bychom poukazovali na možnost globálního spiknutí. Morální hranice mohou v tomto prŕpadě fungovat jako legitimizační prostředek exkluze nezaměstnaných v situaci, kdy „firmy nemají zájem zaměstnávat velkou část pracovníků dlouhodobě“" (tamtéž: 59).

Existence morálních hranic se $\mathrm{v}$ př́padě nezaměstnanosti ovšem projevuje $\mathrm{i} \mathrm{v}$ rámci nižší třídy samotné. Ti, kdo práci mají, shlížejí s nelibostí na jedince pobírající dávky v nezaměstnanosti. Keller uvádí, že místo toho, aby se solidarizovali s hưře postavenými, mají ti nahoře pocit, že lidé pod nimi i nad nimi žijí na jejich úkor. „,[P]ovažují je za parazity. Takto se dívají na nezaměstnané, na přistěhovalce, na všechny, kdo pobírají sociální dávky“ (tamtéž: 95). Protože však Američané mají tendenci hodnotit druhé na základě silných morálních kritérií, umožňuje jim to považovat chudobu za osobní nedostatek (Lamont 1998: 15). Američané raději podporují spíše potřebné děti nebo handicapované, nikoli chudé, kteří si prý za svůj osud mohou sami (tamtéž). ${ }^{8}$

Keller (2010: 150-151) podotýká, že deklasovaní jsou obviňováni z neschopnosti přizpůsobit se normálním poměrům, což ale ve skutečnosti znamená, že se pouze nedokáží orientovat $\mathrm{v}$ neustálé nejistotě ${ }^{9}$ způsobené přechodem organizací na sít’ové uspořádání. Jak

7 Jde o režim, který má přimět nezaměstnané vzít jakoukoli práci, jinak ztratí nárok na sociální dávky (Keller 2010: 44).

8 Lamont (1998: 15-6) ilustruje nelibost amerických dělníků vůči chudým pomocí názoru dvou republikánů: „Neměli bychom dovolit, aby bylo snadné zůstat na podpoře,“ a „nemám rád lidi, kteří všeho jen využívají, pořád jen berou a nikdy nic nevrátí“. Oba jsou rozzlobení proto, že musí platit vysoké daně, aby podporovali chudé, kteří podle jejich názoru „vůbec nepracují a dostávají všechno zadarmo“. Naproti tomu mezi francouzskými dělníky panuje spíše pocit solidarity s chudými (Lamont 2000).

9 O tom, že se symbolická hranice mezi deklasovanými a ostatními prohlubuje a začíná se měnit na hranici sociální, svědčí napríklad snaha o vyčištění městského prostoru od bezdomovců. Tento 
lze ale dovodit z výzkumů Lamont, obviňování obětí ze ztráty práce může být výsledkem působení morálních symbolických hranic, a nikoli snahy legitimizovat působení mechanismů trhu na život společnosti.

\section{Individualizace}

O povinnosti každého jednotlivce nést zodpovědnost za svůj osud, na níž si příslušníci středních i nižších vrstev tolik zakládají, tedy o individualismu rozšiřreném ve středních patrech postindustriálních společností, se Lamont a Keller vyjadřují podobně. „Jeho součástí je přesvědčení, že [...] odměnu získávají ti, kdo si ji skutečně zaslouží, a že každý člověk je pánem svého vlastního osudu“ (Keller 2010: 60). Zatímco Lamont zdůrazňuje, že středostavovští rodiče se svým dětem snaží vštípit ambicióznost, dobrou pracovní morálku a soutěživost proto, že tyto hodnoty mají hned dvojí význam (vyjadřují jak morální hodnotu, tak socioekonomické postavení člověka) (1992: 115), podle Kellera slouží ideologie individualismu k tomu, aby se všem - kromě majetkových a mocenských špiček - zabránilo využívat strategie statusových skupin: ,[U]možňuje, aby uprostřed společnosti i na jejím spodku mohl každý zcela svobodně soupeřit s každým druhým, a tak si navzájem snižovali šance“ (tamtéž: 158). Individualizované strategie pak střední a nižší vrstvy znevýhodňují vůči „skutečně bohatým, kteří si mohou (po splnění svých povinností ke statusové skupině) notné porce individualismu bez rizika doprrát“" (tamtéž: 160). Zatímco těm uprostřed i těm úplně dole ve společnosti jsou vštěpovány zásady individuálního soupeření mezi jednotlivci i celými skupinami, př́íslušníci diskrétní elity postupují prý zásadně společně (tamtéž: 78).

Lamont (2000: 176) nicméně připomíná, že nižší a střední vrstvy v USA mají rozdílné představy o úspěchu. Zatímco př́slušníci středních vrstev povzbuzují své potomky k dosahování cílů konvenčními cestami, nižší vrstvy nahrazují středostavovskou ideologii hodnocení úspěchu kritérii, jako jsou tělesná zdatnost, citová odolnost, bystrost či loajalita. Jednou z nejoceňovanějších vlastností mezi afroamerickými i francouzskými dělníky je ovšem skupinová solidarita. Jak Lamont zjistila dále, zatímco ve světě středních vrstev mohou být úspěšní lidé obdivováni mimo jiné proto, že jejich úspěch ukazuje na internalizaci oceňovaných mravních hodnot, jako jsou již výše zmíněná soutěživost, ambicióznost, či nezlomnost, lidé z nižších vrstev ve skutečnosti odmítají hodnoty „amerického snu“ a nemají zájem o zlepšení svého sociálního postavení ani o vzestup do středních vrstev. Místo toho zdůrazňují vřelé mezilidské vztahy, rodinné hodnoty a solidaritu s ostatními, i hůře postavenými lidmi; soutěživostí a ambiciózností spíše pohrdají. Kellerův závěr ovšem platí pro americké bělošské dělníky, kteří přejímají strategie středních trríd a často se za jejich př́slušníky i považují (Lamont 2000). Ukazuje se tedy, že nejen elity jsou solidární se sobě rovnými a že individualistické životní strategie jsou stále charakteristické spíše pro vrstvy stř̌ední než ty nižší.

postup legitimizuje celospolečenská stigmatizace těchto jedinců. Jak píše Keller: „Dříve se předpokládalo, že bezdomovec je stejný jako ostatní, a pokud dostane př́ležitost bydlet, integruje se jako všichni ostatní. Dnes se má za to, že je to jiný tvor.“ (Keller 2010: 172). 
Symbolické morální hranice se pak v souvislosti s vnímáním úspěchu (který je v různých patrech společnosti, jak bylo řečeno výše, konceptualizován různě) překrývají a navzájem prolínají s hranicemi socioekonomickými, na něž se zaměříme nyní.

\section{Socioekonomické hranice}

Společenský status lze posoudit mnohem rychleji než status kulturní či morální; statky, které lidé konzumují, poskytují okamžitou informaci o velikosti jejich př́ijmů a postavení na společenském žebříčku. Pravděpodobnost nárůstu významu socioekonomických hranic je obzvláště vysoká v zemích s rostoucí geografickou mobilitou obyvatelstva a také v sídlech, kde kvůli velikosti populace převažují méně osobní mezilidské vztahy (Lamont 1992: 85). Data ukazují, že socioekonomické hranice jsou v USA i ve Francii nepatrně významnější než hranice morální či kulturní (tamtéž: 64). Přesto by bylo poněkud unáhlené prohlásit, jako to dělá Keller, že veškeré nerovnosti ve společnosti jsou vlastně založeny na třídních pozicích a že „skutečný kapitál působí jako vnější síla, která formuje osudy jednotlivců a celých sociálních skupin“ (Keller 2010: 166).

Příslušníci amerických středních trríd posuzují lidskou hodnotu na základě společenského postavení častěji než dělníci a cítí se méněcenně ve vztahu k bohatým, mocným a úspěšným lidem. Na rozdíl od dělníků jen málo z nich upřednostňuje osobní integritu před úspěchem (Lamont 1992: 115). Jak připomíná Keller (2010: 65), „boháči s rodokmenem“ byli v USA tradičně považováni za nositele důstojnosti. Ve středních vrstvách USA peníze znamenají (a přinášejí) svobodu, vliv, bezpečí, zkrátka úspěch, který je poměřován výší př́ijmu. Stejný jev popsal už Charles Wright Mills: „Peníze jsou jediným naprosto jasným měřítkem úspěchu a úspěch je v Americe doposud suverénní hodnotou“ (Mills 1966: 406). V základech amerických socioekonomických symbolických hranic proto nacházíme peníze (na rozdíl od Francie). Peníze přináší - jako symbol úspěchu a jako odměnu za jeho dosažení - komfort: velká a drahá auta, domy, exotické výlety, nejmodernější elektroniku. Úroveň komfortu zpětně zrcadlí úspěch, což některé jedince vtahuje do nekonečné spirály konzumu (Lamont 1992: kap. 3). Naopak pro dělníky, příslušníky nižších tříd, je úspěchem spíše jistota a stabilita zaměstnání než vzestupná mobilita (Lamont 2000: 112); afroameričtí dělníci v souvislosti s úspěchem zdůrazňují solidaritu a šlechetnost (tamtéž: 28). Upřednostňování morálních kvalit před socioekonomickým úspěchem pomáhá dělníkům potvrzovat a uchovávat si vědomí vlastní důležitosti a důstojnosti s tím, že postavení člověka nevypovídá o jeho hodnotě (tamtéž: 129).

Socioekonomické hranice jsou tedy v americkém středostavovském prostředí využívány i pro hodnocení explicitně neekonomických oblastí života (Lamont 1992). Mills (1966: 406) k tomu lakonicky dodává, že „,kde životní kariéru určují peníze, tam se vždycky nakonec těší úctě člověk, který je má, bez ohledu na to, jak k nim přišel“". Naopak nižší trrídy mají tendenci oddělovat skutečnou hodnotu člověka od jeho socioekonomické pozice. ${ }^{10}$ Američané zdůrazňují rovnost všech lidských bytostí bez ohledu na jejich postavení ve společenské struktuře, a snižují tak význam socioekonomických hranic mezi sebou a střední třídou; vůči chudým se

10 Tento př́stup podle Lamont odporuje základnímu předpokladu ,amerického snu“, v němž je sociální pozice úzce spojena s bohatstvím (2000: 114). 
však ostře vymezují podobně jako příslušníci středních vrstev, a to na základě silných hranic morálních. To odpovídá Kellerově tvrzení (2010: 95, viz výše), že lidé z nižších vrstev pohlížejí na ty ještě hưře postavené jako na parazity. Snaha přiblížit se těm nahoře a distancovat se od těch dole se tak zdá pro všechny společenské vrstvy (kromě těch nejvýše postavených) typická. Lamont (2000) nicméně ukázala, že francouzští dělníci často pohlíží na bohatší lidi jako na osoby špatných mravů, kteří jsou vykořist'ující a nelidští.

Ve Francii obecně vládne poněkud ambivalentní přístup k penězům - i středostavovští Francouzi si vysoký prŕjem častěji spojují spíše s nižší mírou svobody rozhodování a ztrátou osobní integrity (Lamont 1992: kap. 3). Jako by právě zde platil starý americký zvyk „nedůvěřovat vysoce postaveným a mocným lidem po stránce morální“ (Mills 1966: 398). ${ }^{11}$ Francouzi také vykazují tendence spojovat peníze s popíráním skutečné hodnoty práce spíše než s úspěchem. Pro exkluzi na základě socioekonomických hranic je pro ně důležitější původ a moc (Lamont 1992: kap. 3). Francouzští dělníci, v jejichž světonázoru hraje důležitou roli přetrvávající trrídní boj, považují peníze a moc za zlo spojené s nemorální vyšší třídou (Lamont 2000).

Ve Spojených státech se tedy častěji než ve Francii setkáme s vytvářením symbolických hranic na základě velikosti prŕíjmů. Pro americký rovnostářský přístup k lidem je totiž nelegitimní explicitně posuzovat druhé na základě třídní př́íslušnosti nebo typu vykonávaného zaměstnání. I velmi úspěšní příslušníci vyšší stř̌ední trrídy o sobě tvrdí, že jsou jen obyčejní lidé a není na nich nic zvláštního. Mnoho participantů také údajně považuje všechny druhy práce za stejně rovné, vedoucí pracovníci zdůrazňují, že jsou si rovni se svými podřízenými. Takovéto výroky ovšem ostře kontrastují s významností socioekonomických hranic založených hlavně na penězích a úspěchu, která se projevila v rozhovorech. Většina participantů přiznala, že se cítí být v podřizeném postavení vůči lidem bohatším nebo mocnějším, než je sama, a nadřazená těm, kdo mají méně peněz i moci (Lamont 1992: 79).

\section{K existenci tříd}

Ačkoli podle Kellera $(2010$ : 92, 194) přestali dělníci jako třída existovat a své vlastní postavení považují za neúspěch, Lamont naopak zjistila, že američtí i francouzští dělníci běžně odkazují k tř́́dnímu rozdělení společnosti, mají-li se vymezit vůči výše postaveným skupinám, o kterých mluví jako o lidech typu „Ken a Barbie“ a jimiž pohrdají pro jejich povýšenost (Lamont 2000: 148).

Francouzi ze středních vrstev se sice vyhýbají vytváření socioekonomických hranic na základě prŕíjmů, jsou ale na rozdíl od Američanů ochotni (stejně jako dělníci) posuzovat status na základě trrídní př́slušnosti. Někteří prríslušníci vyšší stř̌ední trrídy dokonce otevřeně

11 To, že se u současných středostavovských Američanů podobná tendence neobjevila, může ukazovat bud' na změnu vnímání bohatství mezi nimi, tj. na změnu symbolické hranice, nebo na skutečnost, že se jedná spíše o přístup tř́́dy nižší; naprríklad Lamont (2000: kap. 3) ukazuje, že američtí dělníci se při hodnocení vyšších trríd zdráhají srovnávat socioekonomické postavení s mravní hodnotou člověka. 
hovoří o svém pohrdání méně prestižními povoláními a považují se za př́islušníky elity (Lamont 1992: 81).

Keller (2010) však ze všech sociálních světů za třídu považuje jen elitu, která údajně splňuje charakteristiky jak třídy o sobě, tak třídy pro sebe. Její členové si uvědomují společné zájmy a kolektivně hájí svá privilegia. Elita nižší i vyšší si navíc ,jako celek podržují charakter statusové skupiny vůči zbytku společnosti, což umožňuje diktovat ostatním podmínky kontraktů“ (2010: 192). Díky tomu mohou oslabovat prvky statusových skupin ve středních vrstvách s cílem ,založit jejich pozici výhradně na tržním kontraktu. Tím se příslušníkủm profesí zabraňuje použít skupinovou strategii při hájení jejich společných zájmů a odsuzuje je to k používání méně účinných individualizovaných strategií“ (tamtéž: 193). Spodním vrstvám pak podle Kellera (tamtéž: 195) hrozí proměna ve stoprocentně individualizovanou masu. Směrem shora dolů prý ,postupně ubývá prvků skupinového statusu a prribývá prvků weberovsky chápaného tržního kontraktu“" (tamtéž).

Hovořit o zániku tříd a vzniku individualizovaných mas dělníků bez třídního vědomí se však ve světle zjištění Lamont $(1992,2000)$ zdá poněkud předčasné. Třídní vědomí se prokázalo jak u francouzské střední vrstvy, jež se považuje za tř́du elit, tak mezi francouzskými a americkými dělníky, kteří se solidarizují nejen mezi sebou, ale i s níže postavenými příslušníky nižších vrstev společnosti.

\section{Kulturní hranice}

Podle teorií kulturního kapitálu rozhodují o výši kulturního statusu jazykové kompetence, vztah k vysoké kultuře a kultivované dispozice; Lamont (1992: kap. 4) ale ukazuje, že pro střední vrstvy hrají klíčovou roli i takové faktory, jako jsou inteligence, seberealizace nebo výše dosaženého vzdělání. O vzestupu významu těchto tzv. postmaterialistických hodnot ve společnosti se zmiňuje i Keller (2010: 157). Druhým, materialistickým dechem ovšem dodává, že kulturní kapitál slouži středním vrstvám jen jako náhražka skutečného kapitálu: „Ti, kdo nemají př́stup ke skutečným privilegiím horních, si skrze vzdělání jednak namlouvají, že ho mohou získat, jednak si monopolizují atraktivnější místa oproti těm, kterým srovnatelné vzdělání chybí" (tamtéž: 141). O tom, že k exkluzi na základě kulturních hranic dochází, svědčí závěry Lamont (1992: kap. 4). Francouzi ze středních vrstev nesnáší omezence a cítí se být méněcenní oproti intelektuálům; intelektuální úspěch považují za úspěch par excellence. Inteligence se dá ale posuzovat na základě různých měřítek: zatímco ve Francii je důležitá schopnost kritického myšlení, intelektuální hravost, výmluvnost a styl, Američané oceňují především kompetenci - kvalifikaci, znalost užitečných faktů a praktické know-how využitelné v běžném životě. To některým přináší pocity podřízenosti vůči lidem, kteří „vědí víc“.

Ve Spojených státech je velmi kladně hodnocena právě seberealizace, intelektuální zvědavost a zájem o vysokou kulturu; Američané středních tříd tedy na ostatních oceňují charakteristiky typické pro střední třídy. Zdůrazňování seberealizace jako znaku vysokého statusu může zároveň znamenat vytváření kulturních, morálních a socioekonomických hranic - nepřímo ji lze totiž považovat za důkaz mravního charakteru a vlastností vedoucích ke společenskému úspěchu, tj. za znak morálního, kulturního i socioekonomického statusu (tamtéž: 100). Kvalifikace a pragmatismus, rovněž oceňované v amerických středních kruzích, jsou 
ve Francii vnímány jako běžně dostupné, a tudíž méně významné pro výši sociálního statusu. Francouzi si naopak cení výmluvnosti, kterou tradičně doprovází další, třídně specifické, kulturní zdroje, jako je znalost vysoké kultury a kultivované vystupování, získané na vysokých školách. Často také odmítají vulgaritu jako znak distance od všedního vkusu, typického pro nižší třídy (tamtéž: 175-177). Aby francouzské stř̌ední vrstvy považovaly jedince za sofistikovaného, je navýsost důležité, aby vedl správný způsob života, obklopoval se správnými věcmi, měl styl, správně si organizoval den a byl kultivovaný, měl vybrané způsoby, mluvu i slovník, zůstával elegantní a nikdy neztrácel tvář; neméně důležitá je distance od vkusu středních a pracujících tříd. Vytváření rozdílů na základě vkusu a životního stylu je podle Lamont (tamtéž: 103) srovnatelné s vytvářením rozdílů na základě třídního původu - jak připomíná Keller, „,[č]lenové diskrétní elity disponují kromě obrovského kapitálu ekonomického též značným kapitálem kulturním, sociálním a symbolickým““ (2010: 71), což střední vrstvy obdivují a závidí, zatímco jim použití stejných měřítek umožňuje opovrhovat příslušníky tř̌íd nižších (tamtéž: 125, 135).

Upřednostňování kultivovanosti a zavrhování všeho běžného a vulgárního je tedy formou socioekonomické hranice - ukazuje na tendence vyhranit se vůči jiné třídě raději pomocí kulturních než socioekonomických rozdílů (Lamont 1992: kap. 4). Francouzští dělníci jsou stejně jako př́slušníci středních tříd ochotni vytvářet hranice na základě kulturního kapitálu a rozdílů; hovoří o pocitech inferiority vůči lidem s rozsáhlejšími kulturními znalostmi (Lamont 2000: 220).

V Americe naopak převládá kulturní eklekticismus. Střední vrstvy odmítají dělat mezi lidmi rozdíly na základě kulturní sofistikovanosti - takové jednání by mohlo být, stejně jako posuzování druhých podle náboženství či etnicity, považováno za bigotní (Lamont 2000: 105). Vládne zde názor, že kultura by měla být demokraticky dostupná; měřítka pro hodnocení kultury se tak podřizují kritériím ekonomickým (Lamont a Thévenot 2000: 311). Ve jménu kulturního rovnostářství Američané brání volný trh s kulturou; mají širší kulturní repertoár a také rozostřené a méně stabilní dělení kultury, tedy slabší kulturní hranice, než je tomu např́klad ve Francii (Lamont 1992: 177). Hodnoty kolegiality, nekonfliktnosti a rovnostářství v zájmu zachování suverenity individuí odsouvají kulturní hranice a povyšují mravní kvality nad ně. Je velmi nepravděpodobné, že by se kulturní distinkce (na rozdíl od morálních) mohly $\mathrm{v}$ americkém prostředí transponovat do socioekonomických hranic, a přispívat tak k vytváření nerovnosti (tamtéž: kap. 4).

Na tomto místě se dostáváme ke konceptu kultury chudoby, jak ho formuloval Oscar Lewis (2006). ${ }^{12}$ Podle něj mají lidé ze středních vrstev sklon soustředit se na negativní aspekty této kultury a negativně se vymezovat vůči jevưm, jako jsou orientace na př́tomnost nebo oddávání se okamžitým požitkům (tamtéž: 410-411). Symbolické hranice mezi světem středních vrstev a deklasovaných tedy vychází z rozdílného př́stupu těchto světů $\mathrm{k}$ praktikám, které jim poskytuje kultura. Jak již bylo řečeno, Američané středních vrstev považují

12 Tento konceptuální model týkající se západní společnosti popisuje její subkulturu, která „poskytuje lidským bytostem návod na život, připravený soubor řešení problémů, a plní tedy významnou adaptivní funkci“ (Lewis 2006: 402). Důležité je zmínit, že mnoho „způsobů chování, které kultura chudoby akceptuje, odporuje ideálům, kterých si váží většinová společnost“ (tamtéž). 
např́iklad schopnost dlouhodobého plánování za žádoucí morální charakteristiku - kulturní rozdíly se tedy mění v morální hranice mezi světy. Deklasovaní na své oddělení od většinové společnosti zase reagují pocity „nepřátelství k základním institucím těch, kteří jsou považováni za vládnoucí tř́́du“ (tamtéž: 406). Naproti tomu jsou francouzské kulturní hranice stabilnější, univerzálnější a více hierarchizující, a tedy s větším vlivem na třídní reprodukci než v USA. Na pracovišti může dokonce kultivované vystupování a vyjadřování nahradit americké hodnoty kolegiality a nekonfliktnosti. Kulturní hranice tedy mohou být i dủležitější než ty morální (Lamont 1992: kap. 4). Porovnáme-li výše popsaný význam kulturních symbolických hranic s Kellerovým postojem ke kulturnímu kapitálu, životnímu stylu a vkusu, zjistíme, že Keller znovu upřednostňuje materialistická měřítka a zůstává u tř́ídní rétoriky - souhlasí s Marcusem (in Keller 2010: 187), když zdůrazňuje, že není ani tak důležitá různorodost životních stylů, nýbrž hierarchie, v jejímž rámci někteří rozhodují, zatímco o jiných je rozhodováno. To ilustruje poukazem na koncept „závislé participace“ Alaina Touraina, podle nějž umožňuje kulturní kapitál střední tř́iě pouze exkludovat ostatní z prŕistupu ke statkům, které jim elity laskavě ponechaly (tamtéž: 141).

\section{Vzdělání}

Vzdělání a jeho různým významům pro jednotlivé sociální světy věnuje Keller obzvláště velkou pozornost:

Umožňuje totiž horním vrstvám budit dojem, že jejich vlastní postavení je založeno v prvé řadě na podaném výkonu, a zároveň to vytváří ostrou hranici mezi středními a dolními vrstvami. Středním vrstvám umožňuje vzdělání cítit se privilegovaně oproti těm námezdním, kteří př́islušné vzdělání nemají. Tím snáze pak zapomínají, že také oni jsou právě jen v pozici námezdních. (Keller 2010: 50-51)

Výše dosaženého vzdělání, která často vede k symbolické exkluzi, je pro střední třídu jedním z nejoceňovanějších znaků př́slušnosti $\mathrm{k}$ vysokému kulturnímu a potažmo socioekonomickému statusu, shoduje se na tomto místě výjimečně Keller (tamtéž) s Lamont (1992, 2000). Právě Lamont (2000: 239) zjistila, že francouzští dělníci si často vysvětlují své nerovné postavení nedostatkem inteligence $;^{13}$ role nadindividuálních mechanismů společenské reprodukce se tak marginalizuje. Je možné, že v názorech těchto lidí se projevuje ideologie společnosti vzdělání, jak o ní píše Keller:

Př́ijmy a postavení horních řídících vrstev se prý odvíjejí od podaného výkonu. Schopnost podávat špičkový výkon je výsledkem kvalitního vzdělání. Princip výkonu spolu s rozšiřováním dostupnosti vysokoškolského vzdělání prý zaručuje, že elita je dnes otevřená jako nikdy dříve. (Keller 2010: 81)

Tato ideologie se podle něj snaží zakrýt hranici mezi elitou a středními vrstvami, kterým se snaží vsugerovat iluzi, „že skrze dosažené vzdělání a vysoký výkon je možné vypracovat

13 Tento př́istup je podporován francouzským vzdělávacím systémem, na jehož selektivní charakter, upřednostňující střední tř́dy, poukázali Bourdieu a Passeron (1990). 
se ve společenské struktuře jakkoli vysoko“ (Keller 2010: 194), a ujišt’uje je, ,že se vzděláním se budou prodávat na trhu práce mnohem lépe, než kdyby ho neměly“ (tamtéž: 50-51). ${ }^{14}$ Dochází tak k údajnému zastírání výhod bohatých v př́stupu ke kariéře a „k legitimizaci stále prríkřejších př́ijmových rozdílů“ (tamtéž: 82).

O prŕtomnosti symbolických hranic mezi sociálními světy lze v souvislosti se vzděláním hovořit také proto, že jeho význam je pro každý ze tří sociálních světů odlišný. Jak ukazuje Keller (2010: 50-51), horní vrstvy si v elitních klubech na vybraných vysokých školách (a kolejích) rozšiřují svůj sociální kapitál, ${ }^{15}$ což jim pomáhá posilovat vědomí sounáležitosti s vlastní skupinou a upevňovat hranice statusové skupiny; materiálně jsou zajištěni natolik, že pro život odborné znalosti nepotřebují. Střední vrstvy se prý živí iluzí, že jim vzdělání v kombinaci s vysokým výkonem umožní proniknout mezi elitu. Díky tomu se legitimizuje postavení elity - vytváří se dojem, že i samotná elita vděčí za své výjimečné postavení podanému výkonu; zároveň se i buduje hranice mezi vrstvami středními a dolními. Střední vrstvy se cítí privilegovaně oproti námezdním, kteří vyšší vzdělání postrádají. Takoví lidé si však chybějící vzdělání mohou kompenzovat zdůrazněním výše příjmu právě před výší dosaženého vzdělání, jak ukázala Lamont $(1992,2000)$, zachovat si tak vědomí vlastní důstojnosti a vyrovnat se se symbolickou exkluzí ze strany vzdělanějších středních a vyšších tříd.

\section{Závěrem}

V tomto textu jsem se snažila ukázat, že při popisu současné společnosti není nutno setrvávat u pojmů teorie tř́id, která klade přehnaný důraz na materiální podmínky existence. Přístup pracující s konceptem symbolických hranic se snaží zkoumat a popsat mechanismy vytváření a reprodukce nerovnosti ve společnosti bez toho, aniž by při tom upřednostňoval socioekonomický status jejích vrstev. V rámci kulturně-sociologického paradigmatu zaměřeného na studium symbolických hranic ovšem stále zůstává nezodpovězeno mnoho otázek. Týkají se konkrétních způsobů vytváření, udržování a změny symbolických hranic; v této oblasti je třeba vykonat ještě mnoho vědecké práce (Lamont 1992, 2000).

Na základě srovnání výsledků studií Michèle Lamont s teorií Jana Kellera se podařilo nalézt a předvést několik zajímavých oblastí, v nichž se symbolické hranice objevují. Co se týče oblasti profesní činnosti, hovoří Keller (2010) o nadindividuálně fungujících mechanismech tržní společnosti, které vykořist'ují všechny kromě příslušníků elity a které se zbavují nepotřebných skupin obyvatelstva, tzv. deklasovaných. Ti mají být v př́padě, že zůstanou

14 Vhodnou ilustrací je způsob, jakým přistupují vysoké školy samy k sobě. Např́iklad Masarykova univerzita provádí v rámci projektu Hodnocení kvality studijních oborů na $M U$ průzkum, jehož významnou část tvoří statistiky uplatnění absolventů na trhu práce, obor jejich činnosti a výše nástupních a stávajících platů (Nekuda, Sirovátka 2010).

15 Francie a Velká Británie mají systém „elitních vysokých škol, na nichž v převážné míře studují právě potomci privilegovaných vrstev“ (Keller 2010: 83). V USA pak „Harvard, Yale nebo Princeton nestačí. $\mathrm{Na}$ čem doopravdy záleží, je exkluzivní přípravka, nebot’ ta určuje, který ze ,dvou Harvardů bude absolvent navštěvovat. Vzájemné vztahy, které navázal v jejích nižších trí́dách, a pověst, které zde nabyl, přecházejí s ním do klubů a klik na vysoké škole: na Harvardu má ty prátele, s nimiž uzavřel přátelství v prrípravce.“ (Mills 1966: 94). 
bez práce, obviňováni ze ztráty zaměstnání ve snaze zastřít skutečný stav věcí. Podle teorie pracující se symbolickými hranicemi však mezi příslušníky světů středních a nižších tříd existují morální hranice. Ti, kdo stojí ve společenské struktuře výše, mají tendenci považovat níže postavené jedince za líné, konfliktní, netolerantní a nedůvěryhodné (Lamont 1992). Obviňování obětí ze ztráty práce může tedy dost dobře být ,jen“ výsledkem působení morálních symbolických hranic mezi světy, a nikoli snahy legitimizovat působení trhu na život společnosti, jak naznačuje Keller.

Podobně také ideologie individualizace, jež se podle Kellera (2010) šíř́ nižšími patry společnosti, má zastírat skutečnost. Elita se s její pomocí údajně snaží ostatní vrstvy přesvědčit, že úspěch, soutěživost a ambicióznost jsou tím, co může po sociálním žebříčku vynést nahoru i je. Střední i nižší vrstvy tuto ideologii přijímají, což je oslabuje při soupeření o vzácné statky, zatímco elita prý postupuje zásadně kolektivně. Kvalitativní rozhovory s př́íslušníky nižších vrstev nicméně ukázaly, že Kellerovo tvrzení neplatí univerzálně. Naopak Lamont (2000) zjistila, že jednou z nejoceňovanějších vlastností mezi afroamerickými a francouzskými dělníky je solidarita. Tito lidé nejeví žádný zájem o vzestup do vyšších vrstev, jimiž na základě aplikace silných morálních hodnot pohrdají. Namísto úspěchu a kariéry staví mezilidské vztahy a solidaritu; soutěživost a ambicióznost jsou jim cizí. Kellerova představa individualizovaných jedinců ovšem platí pro americké bělošské dělníky, kteří přejímají strategie středních tříd a často se za jejich příslušníky i považují (tamtéž). Ukázali jsme nicméně, že nejen elity jsou solidární se sobě rovnými a že individualistické životní strategie jsou stále charakteristické spíše pro vrstvy střední než nižší.

Pokud bychom dnes ve společnosti hledali třídy, najdeme je pouze na vrcholu pyramidy nerovnosti, píše Keller (2010) - jen elita současné společnosti nese charakteristiky třídy o sobě i pro sebe. Ve skutečnosti se ovšem zdá, že o tř́dě lze hovořit i v případě dělníků jak amerických, tak francouzských, a rovněž i v případě francouzských vyšších středních vrstev (ty se dokonce považují za př́slušníky třídy elit) (Lamont 1992, 2000). Proti tvrzení o zániku tříd a proměně deklasovaných v individualizovanou masu (Keller 2010) tak svědčí mj. silné trrídní vědomí francouzských dělníků a jejich solidarita se sobě rovnými i níže postavenými př́slušníky spodních vrstev společnosti.

Ačkoli problematiku kultury a její souvislosti s reprodukcí nerovnosti Keller (2010) spíše opomíjí, krátce bourdieuovsky přiznává, že rozdíly mezi sociálními světy jsou patrné i v oblasti zájmu o kulturu či kvality aktivit provozovaných ve volném čase. Proti sociálně-exkludujícímu pojetí kultury se vymezuje Michèle Lamont, když poukazuje na závěry výzkumů symbolických kulturních hranic v USA. Američané ve svém př́stupu ke kultuře vykazují kulturní eklekticismus, díky němuž nejsou pro jednotlivé sociální světy charakteristické žádné vzorce kulturní spotřeby; exkluze na základě kulturních hranic je tedy ve Spojených státech velmi nepravděpodobná. Zcela opačný jev lze ovšem pozorovat ve Francii, kde kulturní hranice velmi často slouží jako eufemistické vyjádření socioekonomických rozdílů (Lamont 1992). Proto je velmi důležité negeneralizovat a nepřipisovat kulturním hranicím v různých společnostech stejnou důležitost pro reprodukci nerovnosti.

Přístup společnosti ke vzdělání se zdá být jedinou oblastí, kde Kellerův pohled souzní s přístupem reflektujícím existenci symbolických hranic. Keller (2010) i Lamont (1992, 2000) se shodují, že výše vzdělání je pro střední třídu jednou z nejdůležitějších známek 
vysokého kulturního a potažmo socioekonomického statusu. Nižší třídy ve Francii se často domnívají, že za jejich postavení ve společnosti může nedostatek inteligence; američtí dělníci si zase nedostatek formálního vzdělání kompenzují zdůrazňováním výše př́ijmu před výší dosaženého vzdělání (tamtéž). Konečně elitám slouží studium na vybraných kolejích vysokých škol k rozšiřování sociálního kapitálu, nikoli ke získávání dovedností potřebných na trhu práce (o což se snaží střední vrstvy), uzavírá Keller (2010) s Millsem (1966).

$\mathrm{Na}$ reprodukci třídních nerovností se nutně nepodílí výhradně socioekonomické rozdíly mezi sociálními světy, jak to naznačuje Keller (2010). Důležitou roli v životě nižších i středních vrstev hrají také symbolické hranice morální a kulturní, které napomáhají třídní reprodukci tam, kde je nepř́pustné rozdělovat lidi na základě jejich pozice v socioekonomické struktuře. Vyznávání alternativních hodnot pomáhá hưře socioekonomicky postaveným skupinám cítit se mravně na výši oproti bohatším a úspěšnějším lidem, hledajícím štěstí v majetku a zaměstnání. Jde rovněž o způsob, jak si i přes nepřizeň strukturálních mechanismů zachovat pocit vlastní důstojnosti a lidské hodnoty. Při studiu nerovnosti ve společnosti tedy nelze vycházet výhradně z vnějších mechanismů ovlivňujících lidské jednání; důležité je zároveň zjišt’ovat, jak se na svou situaci dívají samotní sociální aktéŕi a jak ji definují sami pro sebe. Slovy Lamont (1992: 192): „Jen pokud poznáme vliv kultury na nerovnost, bude možné překonat její důsledky“.

\section{Literatura}

ALEXANDER, Jeffrey C. Citizen and Enemy as Symbolic Classification: On the Polarizing Discourse of Civil Society. In LAMONT, Michèle; FOURNIER, Marcel (eds.). Cultivating Differences: Symbolic Boundaries and the Making of Inequality. Chicago: The University of Chicago Press, 1992, s. 232-256. ISBN 0226468135.

ALEXANDER, Jeffrey C. The Meaningful Construction of Inequality and the Struggles Against It: A 'Strong Program' Approach to How Social Boundaries Change. Cultural Sociology, 2007, roč. 1, č. 1, s. 23-30. ISSN 1749-9755.

BOURDIEU, Pierre. Distinction: A Social Critique of the Judgement of Taste. 1. vyd. London: Routledge, 1996, xiv. ISBN 0415045460.

BOURDIEU, Pierre, PASSERON, Jean-Claude. Reproduction in Education, Society and Culture. 2. vyd. London: SAGE Publications, c1990, xxvi. ISBN 0803983204.

BRYSON, Bethany. Anything But Heavy Metal: Symbolic Exclusion and Musical Dislikes. American Sociological Review, 1996, roč. 61, č. 5, s. 884-899. ISSN 0003-1224.

EHRENREICH, Barbara. Fear of Falling: The Inner Life of the Middle Class. New York: Harper Perennial, 1989, viii. ISBN 0060973331.

EPSTEIN, Cynthia Fuchs. Tinker-bells and Pinups: The Construction and Reconstruction of Gender Boundaries at Work. In LAMONT, Michèle, FOURNIER, Marcel (eds.). Cultivating Differences: Symbolic Boundaries and the Making of Inequality. Chicago: The University of Chicago Press, 1992, s. 232-256. ISBN 0226468135.

JENKINS, Richard. Pierre Bourdieu. Rev. ed. London: Routledge, 2002, xxii. ISBN 0415285275.

KELLER, Jan. Sociologie střednich vrstev. 1. vyd. Praha: Sociologické nakladatelství, 2012. ISBN 978-80-7419-109-1.

KELLER, Jan. Tři sociálni světy: sociálni struktura postindustriálni společnosti. 2. vyd. Praha: Sociologické nakladatelství, 2010. ISBN 9788074190445. 
LAMONT, Michèle. Money, Morals, and Manners: The Culture of the French and American Upper-middle Class. Chicago: University of Chicago Press, c1992, xxix. ISBN 0226468178.

LAMONT, Michèle. Community and Exclusion in France and the United States. (Working paper na konferenci „The Welfare State at Century's End: Current Dilemmas and Possible Futures.“) 1998. Tel Aviv: University of Tel Aviv, Department of Sociology and Anthropology.

LAMONT, Michèle. The Dignity of Working Men: Morality and the Boundaries of Race, Class, and Immigration. New York, N. Y.: Russell Sage Foundation, 2000, xii. ISBN 0674003063.

LAMONT, Michèle. Symbolic Boundaries. In SMELSER, Neil J., BALTES, Paul (eds.). International Encyclopedia of the Social and Behavioral Sciences. Oxford: Elsevier, 2001, s. 15341-15347, ISBN 0080430767.

LAMONT, Michèle, FOURNIER, Marcel (eds.). Cultivating Differences: Symbolic Boundaries and the Making of Inequality. 1. vyd. Chicago: University of Chicago Press, 1992, xvii, 346 p. ISBN 0226468135 .

LAMONT, Michèle, LAREAU, Annette. Cultural Capital: Allusions, Gaps and Glissandos in Recent Theoretical Developments. Sociological Theory, 1988, roč. 6, č. 2, s. 153-168. ISSN 07352751.

LAMONT, Michèle, MOLNÁR, Virag. The Study of Boundaries in the Social Sciences. Annual Review of Sociology, 2002, roč. 28, s. 167-195. ISSN 03600572.

LAMONT, Michèle, THÉVENOT, Laurent (eds.). Rethinking Comparative Cultural Sociology: Repertoires of Evaluation in France and the United States. 1. vyd. Cambridge: Cambridge University Press, 2000, xv. ISBN 0521782635.

LEWIS, Oscar. The Culture of Poverty. In HIRT, Tomáš, JAKOUBEK, Marek. „Romové “ v osidlech sociálního vyloučení. Plzeň: Vydavatelství a nakladatelství Aleš Čeněk, 2006, s. 402-412. ISBN 8086898768.

MILLS, Charles Wright. Mocenská elita. 1. vyd. Praha: Orbis, 1966.

MOŽNÝ, Ivo. Rodina a společnost. 2. upr. vyd. Praha: Sociologické nakladatelství, 2008. ISBN 9788086429878.

NEKUDA, Jaroslav, SIROVÁTKA, Tomáš. Uplatněni absolventů Masarykovy univerzity 2007-2008 v praxi [online]. 2010. Brno: Masarykova univerzita [cit. 19. 5. 2011]. Dostupné z: http://is.muni. cz/do/1499/metodika/rozvoj/kvalita/Pruzkum_uplatneni_2007_08_WEB.pdf

PAKULSKI, Jan, WATERS, Malcolm. The Death of Class. 1st ed. London: SAGE Publications, 1996, viii. ISBN 0803978391.

PETERSON, Roger, KERN, Roger. Changing Highbrow Taste: From Snob to Omnivore. American Sociological Review, 1996, roč. 61, č. 5, s. 900-907. ISSN 0003-1224.

TILLY, Charles. Identities, Boundaries, and Social Ties. Boulder: Paradigm Publishers, 2005. ISBN 1594511314.

VEBLEN, Thorstein. Teorie zahálčivé třídy. 1. vyd. Praha: Sociologické nakladatelství, 1999. ISBN 8085850710.

WEBER, Max, ROTH, Guenther Roth, WITTICH, Claus. Economy and Society: An Outline of Interpretive Sociology. 1st print. Berkeley: University of California Press, 1978, cx. ISBN 0520035003.

\section{Autorka}

Jitka Sklenářová studuje sociologii na Fakultě sociálních studií Masarykovy univerzity v Brně a v současné době usilovně přemýšlí nad tématem své budoucí diplomové práce. Zajímá se nejen o kulturní sociologii, ale též o klasické sociologické teorie a teorii jednání. Článek vychází z textu stejnojmenné bakalářské práce, jež byla v roce 2011 oceněna Cenou Edvarda Beneše 2. stupně. Kontakt: ytusch@gmail.com 